\title{
Peaaegu nagu inimene Miks ja mida räägitakse lemmikloomadest
}

Maarja Villandi

\begin{abstract}
Teesid
Vaatlen seltskonnas kuuldud ja kogutud lugusid lemmikloomadest. Lemmikloomalugusid jutustatakse tõenäoliselt vähem meelelahutuseks, need on pigem kommunikatsioonifunktsioonis. Tõestisündinud lugude jutustamiseks loomadest on vaja kolme eeldust: kahe või rohkema inimese kokkupuudet, jutustamissituatsiooni teket ja vähemalt ühe seltskonnas viibija resp. jutustaja huvi looma(de) vastu. Loomalood liigitasin teemade järgi järgmiselt: looma soetamise lood; lood looma mõnest erilisest oskusest, omadusest või muudest temaga seotud ebatavalistest või naljakatest seikadest; lood loomade omavahelistest suhetest; loomade toiduga seotud lood; lood rumalatest või taipamatutest loomaomanikest; lood kurjadest või ohtlikest loomadest ning lood lemmikloomade kadumisest ja surmast. Loomadest räägitakse kui lähedastest sotsiaalsetest olenditest, kuid siiski mitte päris nii nagu inimesest.
\end{abstract}

Märksõnad: jutustamine, jutustamiskohad, kommunikatsioon, lemmikloom

Käesolevas artiklis käsitlen tõestisündinud või tõena räägitavate lugude jutustamist loomadest. Kuna jutte koduloomadest on seni üsna vähe uuritud, ei olnud võimalik kasutada ühtegi teadaolevat folklooriuurimise metoodikat. Ligilähedast teemat on seni käsitlenud Virág Lappints ja Dániel Bárt oma ettekandes Narratives about Dogs in an Anthropological Context, mille nad esitasid rahvajuttude 14. maailmakongressil Tartus 2005. aasta suvel (Lappints \& Bárt 2005). Selles vaadeldi mitmesuguseid koerapidamise antropoloogilisi aspekte koertega seotud folkloorsete tekstide ja kirjalike allikate põhjal.

Minu uurimuse eesmärk on aga teistsugune. Toon välja oma kogutud näiteid loomadest räägitud lugude kohta ja analüüsin neid.

Üks põhjusi, miks sedasorti lugusid on siiamaani vähe uuritud, on tõenäoliselt see, et folkloristid üldjuhul koguvad jutte teadlikult ja

http://haldjas.folklore.ee/tagused/nr31/maarja.pdf 


\section{Maarja Villandi}

paluvad neid jutustada, eelistades tihti pikemaid lugusid. Antud juhul on aga tegemist spontaanse ning lühikese jutuvormiga.

Peaasjalikult käsitlen jutte loomadest, kellega inimene kõige rohkem kokku puutub, seega koduloomadest. Neid lugusid saab võtta ka kui teatavat liiki isikukogemuse jutte (personal experience narrative). William Labovi (2001) väitel on suulised isikukogemuse narratiivid osutunud diskursuse uurimise üheks viljakamaks vahendiks, sest nende kõnesündmuste struktuur on ebatavaliselt selge ja hästi piiritletud. Lood loomadest iseloomustavad kindlasti nii loomapidajate kui ka loomasõprade, aga ka lihtsalt loomahuviliste diskursust, aga neid võib vaadelda ka kui kontaktiloomisvõimaluste diskursuse elemente.

Ungari folklorist Ilona Nagy (2000) väidab, et selline jutuvestmise vorm, kus täiskasvanud räägivad üksteisele meelelahutuse eesmärgil lugusid, on Lääne-Euroopa kultuurist kadunud. Seetõttu on minu arvates muutunud olulisemaks just jutustamise kommunikatiivne funktsioon.

Ka koduloomadest rääkimine seob inimesi, soodustab suhtlemist. Oma tähelepanekute järgi võin öelda, et inimesele tänavalt on kõige lihtsam läheneda, kui tal on ühes mõni koduloom. Tõestisündinud või tõena esitatavate lugude jutustamiseks loomadest on vaja kolme eeldust:

1) kahe või rohkema inimese kokkupuude;

2) jutustamissituatsiooni teke;

3) vähemalt ühe seltskonnas viibija resp. jutustaja huvi looma(de) vastu.

Kuigi loomadest rääkivaid nn tõestisündinud lood on jutustaja arvates tõesed, saab neid siiski pidada pärimusjuttudeks. Nagu igasugustel pärimusjuttudel, on ka loomadest räägitud lugudel see omadus, et neid esitatakse teatud ajavahemiku tagant, mis võib varieeruda mõnest hetkest tervete põlvkondadeni ja neid ei esitata mitte üks kord, vaid mitu korda. Samuti ei esita neid alati üks ja sama jutustaja, vaid neid võib olla mitu. Annikki Kaivola-Bregenhøj on põhjalikumalt käsitlenud pärimuslikke rahvajutte ja määratlenud esitamissituatsiooni, mis käib küll pärimuslike rahvajuttude kohta üleüldiselt, aga kehtib ka loomadest jutustatud lugude puhul:

Esitussituatsioonis jutustaja meenutab ja sõnastab folklooriainese, mida ta soovib oma kuulajatele edasi anda. Seda si- 
tuatsiooni mõjutavad nii mäletamisprotsessi seadused kui kõik muud tegurid, mida on teadaolevalt seostatud jutustuse kui traditsiooni saadusega. Mida põhjalikumalt töötati läbi jutustusse puutuv informatsioon vastuvõtmise faasis, seda kergem on seda mäletada meenutamise faasis. Ning mida pikem on ajavahemik kahe esituse vahel, seda vähem mälukilde on jutustajal kasutada. Sellisel juhul tuleb tal toetuda üldistele teadmistele sedasorti juttudest või tema käsutuses olevatele jutuskeemidele (Kaivola-Bregenhøj 2000: 36).

Jutustamine põhineb eelkõige jutustaja keelekasutusel, kelle oskus kasutada verbi kõneviise, sõnavara, grammatilisi reegleid ning muude stilistiliste kujundusvõtete ja semantiliste eristuspõhimõtete valdamine määrab jutustuse kommunikatiivse mõju (vt Dégh 1983). Helmut Fischeri arvates toob jutuaines esile jutustatava sisu sündmusena või inimeste kogemusena.

Tegelik sündmus ja tõeline kogemus on kordumatud. Need on ainukordsed ja juba möödunud. Jutustaja jutustamistegevuse kaudu esitatakse tulem eelnimetatust jutu vormis (Fischer 2001).

Lemmikloomadest rääkimise puhul ei tohi jätta märkimata, et sel puhul on tegu ka nn õpitud teemaga: lemmikloomadest kui üldarusaadaval ja alati eakohasel teemal õpetatakse jutustama juba lasteaias ja algkoolis (nt Hiisjärv 2004), hiljem on see üks kohustuslikke teemasid võõrkeele õppimisel (vt nt Storytelling 1997) jne.

Kõigepealt esinen jutustajana ise ja selgitan, kuidas sai alguse minu huvi loomajuttude vastu. Siingi on juba teatud ajaline vahemaa ja ma ei pruugi suuta täpselt kajastada, mida tundsin ja mis olid minu motiivid tol hetkel, kui hakkasin loomalugusid kirja panema.

Eestis lubatakse harva lemmikloomadega kohvikusse, aga Belgias on koeraga kohvikukülastaja üsna tavaline. Et tahtsin õppida flaami keelt ja enamik mu tuttavaid rääkis minuga kas inglise või prantsuse keelt, otsisin kontakti võõrastega. Valisingi välja need, kellel oli kaasas mõni loom. Esitasin küsimusi looma kohta. Võin kinnitada, et see on võõrale tunduvalt mõistetavam suhtluse otsimise viis, kui hakata ilmast rääkima (välitööde käigus kasutatavatest võimalustest informandiga jutule saada vt nt Jackson 1987). Loomaomanike lähedust otsivad sageli ka nn heatahtlikud vanaini- 


\section{Maarja Villandi}

mesed, kes looma vägisi söötma kipuvad. Korra nägin pealt, kuidas peremees ühe niisugusega pahandas. Tema koer söövat ikka spetsiaalset toitu, mitte igasugust. Looma söök oli üldse üsna tavaline loomi puudutav jututeema. Teine asi, mida üks koeraomanik armastas rõhutada, oli see, millal loom koju minema peab. Ta nimetas oma koera direktoriks, sest koer määras, millal peremees koju läheb. Veel oli juttu koera tõust. Erinevalt Eestist selgus, et Belgias on kõik tõukoerad. Üks, keda pidasin esialgu välimuse järgi krantsiks, osutus näiteks hollandi laevakoeraks.

Eestisse tagasi jõudnult hakkasin aeg-ajalt loomalugusid üles märkima. See ei olnud teaduslik huvi, vaid pigem tunnetuslik, emotsionaalse värvinguga. Loomalugusid räägitakse meeleldi, eriti koduses õhkkonnas ja ka muidu kohvilauas. Mõnda neist räägitakse eriti mahlaka väljendusviisiga: vahel laskutakse lüürilistesse mõtisklustesse, vahel kasutatakse, vastupidi, lausa obstsöönseid väljendeid. Olen püüdnud seda keelelist värvikust ka kirjapanekutes säilitada. Üles märkinud ei ole ma neid kuigi palju. Lugusid olen kindlasti kuulnud palju rohkem ja neid kuulen veel edaspidigi. Kirjapanemise varu jätkub alati. Ma ei ole neid lugusid küll teadlikult küsinud - kõik kirja pandud lood on räägitud spontaanselt. Mõnede lugude kuulmine jääb aastate taha. Nii ei pruugi kõik detailselt meeles olla. Lisaks oma kogutud materjalidele olen kasutanud ka Mare Kõiva Rootsi (19961999) ja Austraalia (2001) eestlaste juures lindistatut.

Räägitakse kõigist koduloomadest, aga kassidest ja koertest kõige rohkem. Eelkõige sellepärast, et minu suhtluskonnas peetakse neid loomi üleüldse kõige sagedamini. Põhjus on ilmselt selles, et ma lävin põhiliselt täiskasvanud linlastega. Täiskasvanud ei pea üldjuhul närilisi, nagu näiteks rotid või hamstrid, ja tänapäeva linnainimesed ei pea mitte ainult lehmi ega lambaid, vaid isegi mitte küülikuid (v.a eelkõige laste tubased dekoratiivloomad) ega kanu ja parte, mis veel kolme-nelja aastakümne eest oli väiklinnades ja agulites tavaline. Eksootilisi loomi, nagu madusid või kilpkonni, peetakse aga harva. Närilistest räägitakse rohkem seoses lastega, näiteks, et näriline on salaja, vastu vanemate tahtmist võetud või et laps ei viitsi teda hooldada. Need pole siiski enam loomalood, vaid lood lastest. Ka leidub täiskasvanute seltskonnas alati keegi, kelles närilised või mõned nende omadused vastumeelsust tekitavad. Üks levinumaid vastumeelsuse põhjustajaid on roti paljas saba. Seetõttu katkestavad nad need lood sageli oma märkusega á la "ära räägi sellest vastiku palja sabaga elukast”. Koera- ja kassilugude 


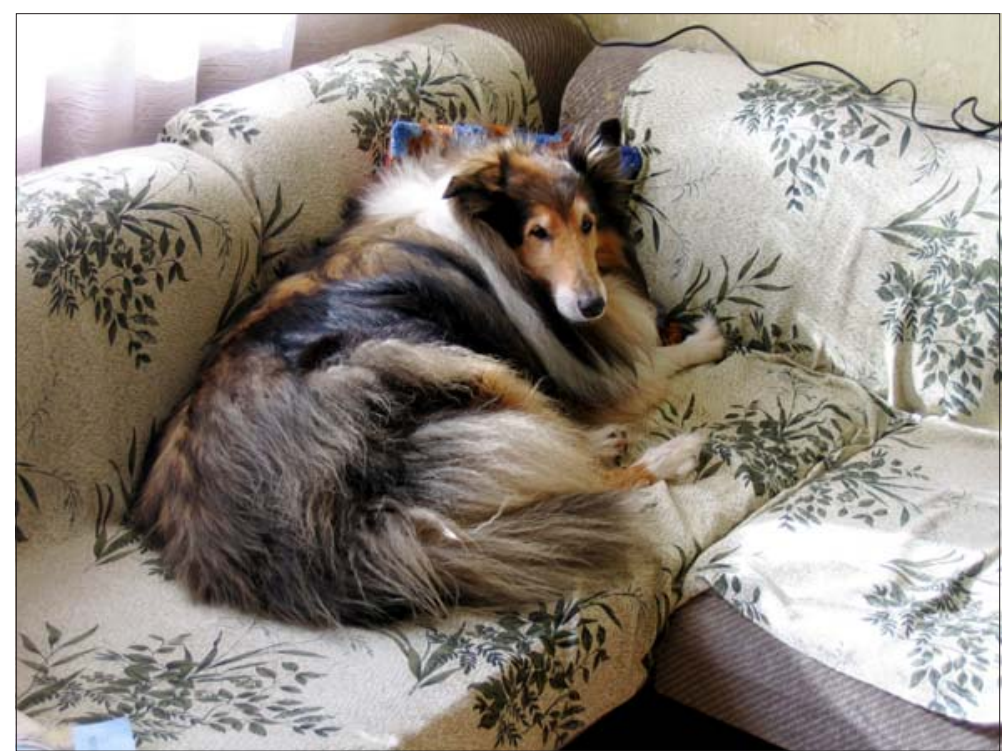

Foto 1. Lemmikloomast räägitakse tihti peaaegu nagu kaasinimesest. Umbes sama tihti lubatakse ta ka tugitooli või diivanile. Maarja Lõhmuse foto.

puhul aga seda ohtu ei ole. Neid kuulatakse üldjuhul meelsasti. Harva, kui keegi julgeb väita, et talle ei meeldi kassid või koerad. Selline väide saab pealegi enamasti sõjaka vastureaktsiooni.

Inimesed kujutavad loomi inimlike omaduste kaudu. Ka nimetatakse loomi mõnikord inimese sünonüümidega, näiteks on isast koera nimetatud härrasmeheks. Ka olen ise kuulnud vana emast koera nimetatavat koeravanamutiks. Ka meenub, kui ma külastasin kunagi ühte vanaema sõbrannat, kellel oli ilus emane kass, nimeks Jelizaveta. Kui küsisin, miks nii peen nimi, siis ta vastas: "Aga ta on ju nagu vene naisterahvas." Ka ei ole midagi haruldast emasloomade nimetamises preiliks või prouaks, mõnikord ka tüdrukuks. Isasloomade puhul kasutatakse tihti poisi nimetust. Ühel korral oligi koerale nimeks pandud Poiss. Samuti omistatakse loomale inimlikke omadusi. Loom võib olla kade ja ahne, ka kaval ja tark, kuri või sõbralik. Kasse peetakse isepäisteks, kuna koer on jällegi truuduse sümbol. Ka räägitakse sellest, et loom midagi teab või teeb näo, et ei tea midagi. Inimese mõistes loom teeb pahan- 


\section{Maarja Villandi}

dust, varastab, meelitab. Mõnda inimest või nähtust loom armastab või vihkab.

Suurt erinevust laste ja täiskasvanute loomalugudes ei ole. Kui täiskasvanu räägib kassist või koerast, siis laps kiisust ja kutsust. Ka on märgata, et kui täiskasvanu räägib loomast, kes tal lapsepõlves oli, siis nimetab ta seda kiisuks või kutsuks. Hilisemas eas saadud loomad muutuvad kassideks ja koerteks. See ei ole absoluutne reegel, aga tendents on märgatav.

Loomadest räägitakse seltskondades, kus on mõni praegune või endine loomapidaja. Ka siis, kui seltskonnas on võõraid, on loomad parim jutuaine tutvuse sobitamiseks. Kui seltskonnas on kõik loomapidajad, siis tarvitseb kellelgi küsida: "Mis sinu kass teeb?" ja juttu jätkub kauemaks, kui kasutada tuntud reklaamilauset. Väga lihtne on loomadest rääkida lastega, sest nende omavahelised tutvused sobituvadki tihti sellel pinnal, mis loom kellelgi on. Inimeste arv seltskonnas, kus loomadest räägitakse, ei ole kuigi määrav. Intensiivsem on jutt siis, kui loomadest räägib kaks loomahuvilist omavahel.

Loomalood liigitasin teemade järgi järgmiselt:

1) looma soetamise lood;

2) lood looma mõnest erilisest oskusest, omadusest või muudest temaga seotud ebatavalistest või naljakatest seikadest;

3) lood loomade omavahelistest suhetest;

4) loomade toiduga seotud lood;

5) lood rumalatest või taipamatutest loomaomanikest;

6) lood kurjadest või ohtlikest loomadest ja

7) lood lemmikloomade kadumisest või surmast.

Looma soetamise lugude alla kuuluvad lood looma saamisest, talle nime panemisest ja ka looma soo määramisega seotud viperustest. Looma soetamise lugudes on juttu sellest, kuidas inimene on endale looma saanud. Nii on võimalik, et ta looma ostis, talle kingiti, ta leidis mahajäetud looma või loom tuli ise tema juurde. Üks näide, mida mulle on jutustatud:

Mu õe kaukaasia lambakoer Räksi on leidlaps. Õe pere elab Vääna kandis Naage külas. Nemad elavad küll endisest suvilaste ümberehitatud majas, kuid tunnevad laiemalt kohalikke. Kohalik metsavaht on ka tuttav, ja too olla selline äpu, kellel kõik asjad ebaõnnestuvad. Pealegi on ta aravõitu. Kord 
tulnud metsavaht siis mu õemehe manu, et rebaseraudadesse jäänud noor koer kinni, mis teha. Õemees aitas looma lahti ja viis koju. Oli noor kaukaaslane. Hakkas peremeest otsima, kuulutustega ja igat muud moodi, aga ei ainsatki jälge. Ilmselt oli loom metsa lahti lastud eesmärgiga temast lahti saada. Nii saigi õde endale koera. Räksist on neil hea ja kuri valvur kasvanud, aitab öösel naabritegi varal silma peal hoi$d a$ (naine, sünd 1955, jutustatud 2003 Tartus).

Kui ülaltoodud näide jutustas looma leidmisest kellegi teise poolt, siis on tuua ka näiteid selle kohta, et loom ise tuleb inimese juurde. Selle jutustas mulle sõbranna.

Kord oli hoovi peal kiusatud ja piinatud vesihall kassipoeg. Koer oli teda purenud. Andres nägi seda pealt. Kassipoeg tuli abiotsivalt tema juurde ja ta võttiski looma vastu, sest "kui kass ise sinu juurde tuleb, peab ära võtma" (naine, sünd 1977, jutustatud 2002 Tartus).

Selles näites, nagu näha, on ka põimunud uskumus seoses loomadega.

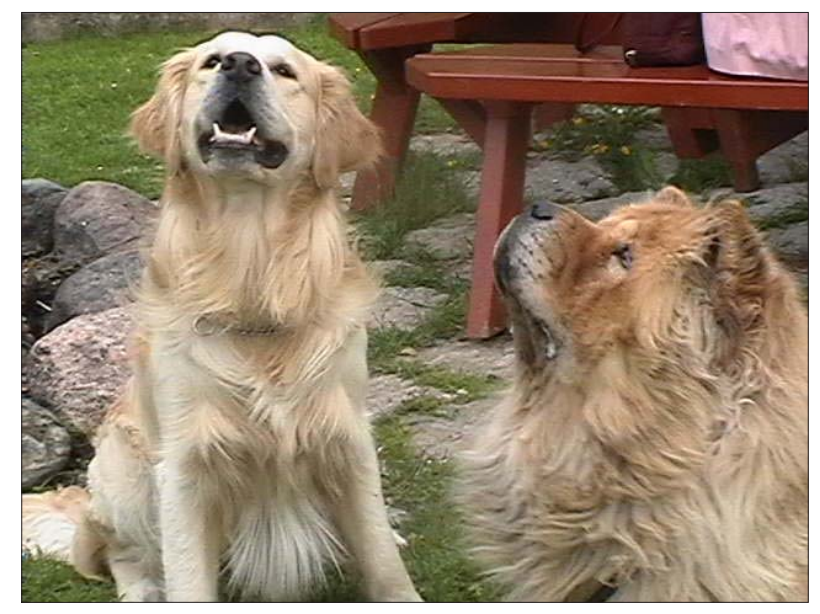

Foto 2. Aiapeol kaasa löövad kuldne retriiver Bosse ja tšau-tšau Cassie on oma pererahva lemmikud ja ka sagedane jutuaines nii sõprade kui juhututtavate ringis. Maarja Lõhmuse foto. 


\section{Maarja Villandi}

Mis puutub nimepanekusse, siis on märgata, et nimi pannakse kas vastavalt traditsioonile (näiteks kui võetakse uus kass või koer, pannakse talle eelmise nimi - minu isa vanematekodus on näiteks kõik kassid alati olnud Antsud ja nende peres on kassidest rääkimisel ants muutunud üldnimeks), peremehe eelistustele (näiteks mõne kuulsuse nimi, kord pandi kassi nimeks Toto Cutugno) või mõnele looma iseloomulikule omadusele (vesihalli kassi nimeks pandi Hallu). Mõnikord pannakse loomale lihtsalt selline nimi, millele ta reageerib (kass nimega Keegel).

Tõukoerte puhul on nime panekul määrav algustäht. Mõnikord pannakse tõukoerale eeskirjade tõttu veider ja võõrapärane, kuid kutsutakse teda mingi lühema ja suupärasema nimega:

Meie vuntsi ametlik nimi on Umberto Uno Marland. Marland on tal isa poolt, ma ei tea, kas see on neil perekonnanimi, aga olen vaid kuulnud, et kui on Marland, siis see on peaaegu nagu kvaliteedimärk Eesti koerailmas. Eesnimi pidi algama U-tähega. Kui me sellele pärdikukarjale nimesid nuputasime, siis esimene nimi tuli meil Umberto Eco eeskujul ja kuna Mac olnud pärast surnuna sündinud kutsikat esimene ellujäänu, siis tuli Uno, esimene. Aga nimi, millele ta reageerib - Macoli juba enne valmis mõeldud. Kõik šotlased on ju Mac'id, pealegi on see lühike ja lihtne. Koer ise saab ka kohe aru. Teiste loomakeste nimesid ma eriti ei mäleta, üks igatahes oli Unforgettable. Ja hü̈̈nimed on Tartus elaval isasel Bono ja koju jäänud õel Milano (naine, sünd 1956, jutustatud Tallinnas 2003).

Aeg-ajalt räägitakse looma saamisest ja nimepanekust pikemaid lugusid. Üks kuuldud lugu on selline:

Leidsime majast karvase kassipoja. Arvasime, et ta on täiskasvanud emane, aga hakkas järjest suuremaks kasvama. Siis selgus, et ta on veel poeg ja isane. Ta kasvas ülisuureks, nagu mõni koer ja nii ta saigi nimeks Kutsa (naine, sünd 1972, jutustatud Tartus 2000).

Loomade sugu määratakse algul ekslikult, seepärast võib loom saada ka n-ö vale nime. Tavalisem paistab olevat see, et emast peetakse isaseks. Siinkohal üks tavalisema süžeega näiteid. Vanaema jutustas: 
Kunagi võtsime pealtnäha täitsa tavalise kassi, aga panime nimeks Jass - pärast oli koška Maška (naine, sünd 1924, jutustatud 2002 Tallinnas).

Kõik kassiomanikud aga ei saa päris tavalisel viisil kassi tegelikku sugu teada. Alltoodud loos esineb jutusüžee, et isaseks arvatud kass sünnitas ootamatult pojad.

Kassi peeti Jackiks, aga tuli välja, et ta on hoopis Jaqueline. Maja ümbruses nimelt käib üks ühiskondlik isane kass, keda kutsutakse Must Panter. Must Panter ronis sellele oletatavale Jackile otsa. Poiss pistis röökima, et Must Panter on pervert, aga võimatu, Must Panter ei eksi sellistes asjades. Nii ongi kass nü̈̈d Jaqueline. Mõne aja pärast oligi tiine (jutustaja mees, sünd 1941, jutustatud Tartus 2004).

Võimalik, et viperused looma soo määramisel on tingitud ootustest looma soo suhtes. Tihti eelistatakse isaseid, sest emastega käib kaasas paljunemishirm.

Mõnikord ei peeta ainult ühte looma korraga, vaid neid võib olla mitu, kas siis ühest või eri liigist. Siis tulevad loomulikult jutuks ka loomade omavahelised suhted. Näiteks on üks vanem üksik mees, kellel on kaks koera. Üks on suur ja teine väike. Ta kirjeldas loomade suhteid selliselt, et suurem on rahulik, aga väike võib aegajalt hambad sisse lüüa, kas või naabrikoerale, kes on ometi temast palju suurem. Suurele koerale see aga ei meeldi ja siis ta justkui käratab väiksele peale, et mis sa, tatt, siin klähvid. See pidi mõjuma.

See näide oli kergelt hierarhilise alatooniga. Väga sagedane on loomade omavaheliste suhete juures võistlusmoment. Tihti võisteldakse perenaise või peremehe tähelepanu pärast.

See vanaema Käpu oli üks igavene kade kass. Ta tuli vanaemale sülle ainult siis, kui tal juba teine kass süles istus, sest siis sai sooja koha pärast kakelda (artikli autori, sünd 1977, enda repertuaari kuuluv lugu).

Inimesi innustab loomadest rääkima mõne looma eriline omadus ja ebatavalised seigad. Need on kas erioskused, veidrused, $\mathrm{nn}$ kõnevõime, loomade tembud või loomade omavahelised tülid. Erioskus on tavaliselt mõni inimlik tegevus, mille tegemist inimene 


\section{Maarja Villandi}

loomalt üldiselt ei eelda. Sageli peetakse mõnd käitumisveidrust või tempu looma ebatavaliseks tarkuseks. Üks mu tuttav on rääkinud järgmist lugu:

Kui ma väike olin, siis võtsid vanemad kassi, sest ta oli tunduvalt ilusam kui tavaliselt. Nimeks pandi Tito. Ükskord mu ema oli raskesti haige. Pidi otsad ära andma. Tal olid roos ja kopsupõletik korraga. Jalg oli paistes nagu pakk. Kutsusime kiirabi. See oli üks umbkeelne arst. Ta ainult sõimas, et mis me teda tülitame, ei ole siin mingit roosi ega kopsupõletikku. Siis kass kuulas seda pealt. Talle see jutt ei meeldinud. Saba tegi vonks-vonks. Korraga hüppas ta kiirabiarstile kintsu ja lõi kü̈̈ned valusasti sisse. Selle peale arst muutis meelt: "Vist on jah" (mees, sünd 1963, jutustas 2001. aasta paiku Tartus).

Ka võib looma eripärade hulka kuuluda mõni veider liigutus või maneer.

Käisin Hiiumaal külas ühel vanaema sõbrannal. Tal oli kolli, kes armastas hüpata ümber iseenda. Perenaine arvas, et viga koera närvisüsteemis (artikli autori, sünd 1977, enda repertuaari kuuluv lugu).

Loomad teevad mõnikord ka häälitsusi, mis inimese kõrvale tunduvad sõnana. Üks mu tuttav räägib oma koerast, kes küsib õue häälitsusega õu-õu. Alati ei pruugi häälikute moodustamisel mingit inimesele arusaadavat tähendust olla. Nii ütles minu vanaisa hundikoer naomi-naomi-naom, mida mu vanaisa nimetas koerakeelseks jutuks. Muude häälitsuste kohta ta nii ei öelnud.

Tihti kumab juttudest läbi see, et kui mõnda omadust või tegu peetakse inimese puhul negatiivseks, siis looma puhul positiivseks või vähemalt huvitavaks või isegi koomiliseks, eriti kui sellega kaasneb mõni looma ebatavaline võime. Järgmises näites on selleks looma ebatavaline jõud. Lugu rääkis minu Belgia sõber.

Kui olin laps, oli meil ebatavaliselt suurt kasvu kass. Meil oli külas onu, kellel loomadega eriti kogemusi ei olnud. Kass oli onu toas. Onu oli vist kehvas tujus ja tegi ühe äkilise liigutuse, mille peale kass ärritus. Siis hüppas kass vastu akent ja aknaklaas läks katki (mees, sünd 1949, jutustatud 2001. aasta paiku). 


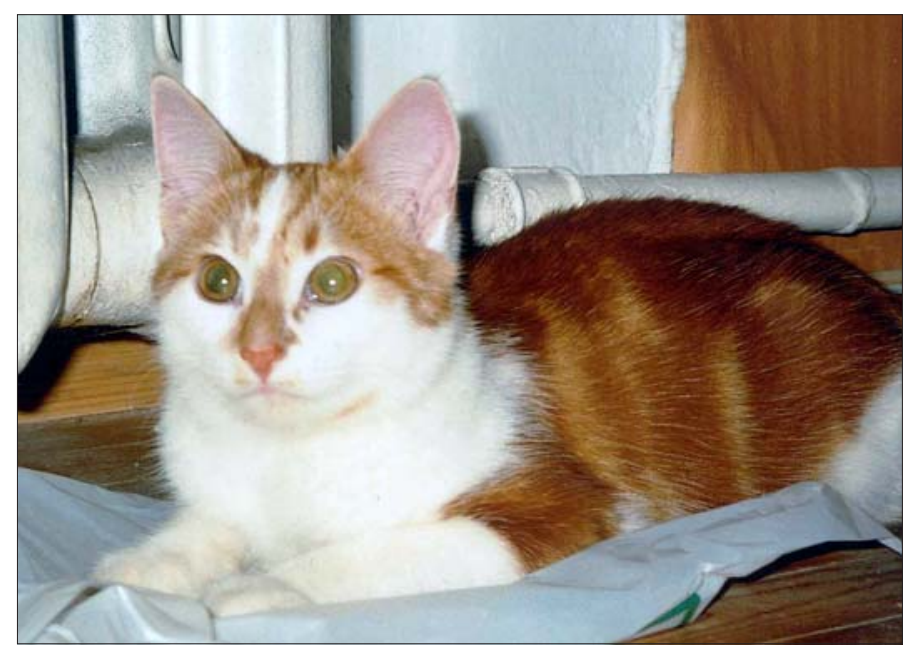

Foto 3. Kass kui jutukangelane - eelkõige armas, kena ja tark, kuid vahel ka kaval ja kiuslik. Kui ta on veel haruldasemat karva, antud juhul punane, nagu pildil olev Kratsu, siis jagub jutte sellevõrra rohkem. Rein Laiveriku foto.

Kõigepealt toon välja ühe inimeste puhul taunitava nähtuse. Inimsilmale tunduvad koomilised loomade omavahelised tülid, eriti siis, kui väiksem suurema paika paneb, mis tähendab tihtipeale, et kass paneb koera paika. Paldiskis elanud tuttav rääkis:

Paldiski turul sai suurepärase tsirkuseetenduse. Sattunud vastastikku üks valge kass ja keskmise suurusega krants. Krants läinud liiga ligidale. Kassile see ei meeldinud. Siis ta susises ja äigas krantsile käpaga nina pihta, nii et kassist mitu korda suurem loom kiunudes minema jooksis. Rahvas naeris täiest kõrist (mees, sünd 1954, jutustatud Paldiskis).

Kassidel on veel teisigi kavalusi, mille abil koerast üle olla. Mu Belgia sõber rääkis:

Lapsena nägin järgmist pilti. Suur hundikoer oli kassile liiga lähedale sattunud, aga kass ei löönud araks, vaid kargas hundikoerale selga ja lõi talle kõigi nelja käpa kü̈̈ned sisse. Kus siis alles ratsutas! Ja hundikoer aina kiunus ja kiunus (mees, sünd 1949, jutustanud Antverpenis). 


\section{Maarja Villandi}

Armastatud jututeema on loomade tembud, sealhulgas üks levinumaid varastamine, mida inimese puhul peetakse keelatuks või vähemalt taunitavaks. Lemmiklooma puhul aga peetakse seda millekski huvitavaks või teinekord lausa kangelaslikuks. Kohati muutuvad lood varastavatest loomadest kui peaaegu inimesega võrdsustatud pereliikmetest sellisteks, mida Bengt Holbek on nimetanud perekonna anekdootideks (Holbek 1990). Näiteks rääkis üks Belgia flaam oma kassist:

See kass oli väga tark. Ükskord olid naabrid küpsetanud fooliumis kalli kala neljale inimesele, aga kala oli järelvalveta jäetud. Aken oli lahti ja kass hüppas naabrite aknast sisse. Ta ise ei olnudki nii suur, aga kala võttis ta koonu vahele ning vedas aianurka ja mattis sinna maha. Naabrid muidugi karjusid prantsuse keeles, et kassiraisk on kala ära varastanud, aga mingit pahandust sellepärast naabritega ei tulnud (mees, sünd 1949, jutustatud Antverpenis).

Mu Haapsalus elav sõbranna rääkis oma suurest dogist:

Kui külalised tulid, siis panin taldriku kookidega elutuppa. Läksin külalistega korraks kööki. Koer jäi tuppa. Tulin külalistega mõne aja pärast tagasi - koogitaldrik oli tühi. Koer lesis diivanil ja vaatas sellise näoga, et mina ei tea midagi. Seepeale ehmusin, et ma ju ei mõelnud, et laud on nii madal ja koer on nii kõrge (naine, sünd 1971, jutustatud Haapsalus).

Varguslood käivad enamasti selle kohta, mida loom varastab inimese tagant, aga varastada võivad nad ka üksteise tagant. Need ei ole küll päris puhast tüüpi lood ja põimuvad lugudega loomade omavahelistest suhetest, aga siiski annavad pildi sellest, kuidas kujutatakse looma poolset vargust inimese suu läbi. Minu vanaema rääkis ikka ühest varganäost kassist:

Kassi nimi oli Käpu, sest ta käperdas kogu aeg midagi. Lisaks inimese toidule hakkas ta kü̈̈si taha ajama ka teiste kasside toidule. Kasse oli kolm. Igaühel oma kauss. Käpu hakkas alati esimesena sööma kellegi teise kausist. Oma kauss tuli meelde siis, kui ta oli teiste kausside juurest eemale peletatud või olid need tühjaks söödud (naine, sünd 1924, 2003 jutustanud Tallinnas). 


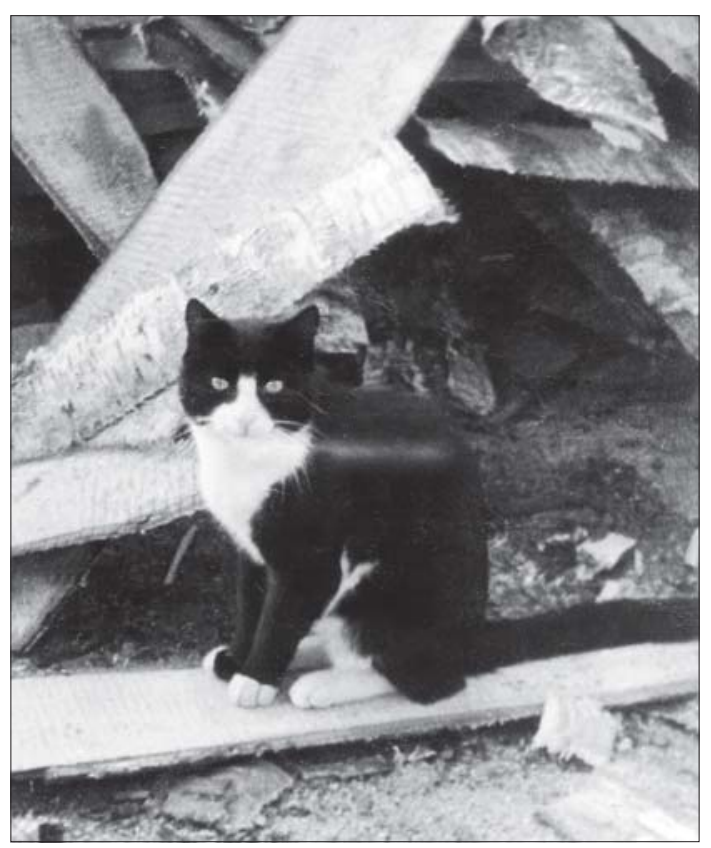

Foto 5. Kass Virka elas veel sedavõrd iseseisvat kassielu, et temast põlvest põlve kanduvaid lugusid ei räägita. Foto erakogust. 1950. aastate lõpp.

Loomade üksteise tagant varastamise lugu tean ühe üksiku vanema mehe käest, kellel on kaks koera:

Üks on mul suur hundikoer, teine väike krants. Hundikoeral on eeldatavalt loomulikult suurem isu kui väiksel krantsil. Siis juhtub tihtipeale niimoodi, et suur koer tühjendab nagu muuseas ka väikse koera kausi, mille peale ma ikka ütlen: "Noh, väikse toidu keerasid ka perse" (mees, sünd 1921, jutustatud Kursi khk, Laeva k 2005).

Mis vahe on kahel ülaltoodud jutul? Kui üksteise tagant varastavad kassid, siis peetakse selle tagamaaks pigem kassi kavalust või kättemaksuhimu. Kui aga üks koer teise tagant söögi ära sööb, siis sellepärast, et tal on lihtsalt suurem isu kui teisel. Siin mängib rolli ka see, et koerad erinevad suuruselt märgatavalt rohkem kui kassid. Võistlusmoment aga ei jää tähelepanuta koertegi vahel. 


\section{Maarja Villandi}

Minu vanaema ja vanaisa juures elas kaks koera, aga vahel käis neil külas lisaks ka tädipoegade koer. Kõik olid segaverelised ja suhteliselt hea isuga. Vanaema ja vanaisa söötsid koeri lihtsa toiduga, aga tädipoegade koera ilmselt veidikene poputati, sest vanaema jutu jörgi oli ta "kodus nii peenike, et isegi vorstinahk ei lähe sisse”. Kui koer jälle vanaema ja vanaisa juurde hoiule toodi, siis ütles vanaema jälle, et "aga siinigasugune pask läheb sisse”. Peaasi, et teised ei saaks! (artikli autori, sünd 1977, enda repertuaari kuuluv lugu).

Et loomad võivad toidu pärast võistelda ja toit kuulub looma igapäevavajaduste hulka, on loomatoit samuti üks olulisemaid jututeemasid seoses loomadega. Loomatoiduga seoses arutletakse ühelt poolt selle üle, milline toit on loomale kasulik, mis tekitab allergiat. Üks tuttav on rääkinud:

Mina oma koerale - see on taksikoerale sarnanev segavereline - poest koeratoitu osta ei või - see tekitab tal allergiat ja karv hakkab maha tulema. Arvasime algul, et seda tekitab ainult kuivtoit ja seda enam ei ostnud. Ükskord pühade puhul ostsime koerakonservi - aga ikka mõjus see looma karvastikule halvasti. Aga putrusid, supijäätmeid ja muud inimesetoitu sööb loom mõnuga ja on hea tervise juures (naine, sünd 1954, jutustatud 2001 Tartus).

Teine loomaomanik aga räägib:

Koer tahab mul väga leivakuivikuid, aga ma ei või talle neid anda. Vahepeal andsime, koer ka eelistas tavalist toitu koerasöögile, kuigi me olime talle ostnud spetsiaalset, kallist koeratoitu. Ta isegi ei võtnud seda suhu, kui juba tavalise toidu maiguga harjus. Aga siis selgus, et tekkis kõõm ja nahk hakkas sügelema ning loomaarst arvas, et ilmselt on see loomse valgu üleküllusest ning käskis anda vähemalt kuu aega ainult koeratoitu (naine, sünd 1956, jutustatud 2003 Tartus).

Teine teema on loomade kummalised toidueelistused - näiteks lugu kassist, kes armastas kurki ja kapsast - ning kolmandaks linnalegendina levivad lood kunstliku koeratoidu ohtlikkusest. Selle näiteks sobib Tartus ringlev lugu, millel kuuldavasti on ka tõepõhi all: 
Annelinnas elas üks bullterjer - see on see sea moodi koer, kes halva kasvatuse juures muutuvat koguni ohtlikuks. See koer liikus koos ühe rotveileriga, nad kuulusid ühele loomaarstile. Bullterjeril oli üks kõrv must ja lontis, ta nimi olevat olnud seetôttu Notsu. Aga seda Notsut enam pole. Perenaisel olnud kiire ja ta andis talle koerte kuivtoitu ilma leotamata ning koer oli söönud seda liiga palju ning kui see siis maos niiskust sai ja paisus, oli tal magu lõhki läinud. Loom jõudnud küll kliinikus operatsioonilauale, kuid suri siiski (naine (loomaarst), sünd 1955, jutustatud 2003 Tartus).

Eelnev lugu oli näide rumalast koeraomanikust. Ka on näiteid sellest, et teisitigi on looma tervist rikutud. Kuulsin ühe kolli perenaise lugu:

Meie oleme ikka loomapidamises paiguti üsna võhiklikud, eriti, mis loomahaigustesse puutub. Ja eks see koeraga väljaskäiminegi ole paiguti juhuslik ja puudulik. Kord olin ise kolm kuud välismaal, mees ja poeg pidid looma hooldama. Poja koer see ju tegelikult ongi, aga eks need toitmised ja muud hooldamised harilikult naiste peale peredes ju jää. Mehed siis justnagu hooldasidki. Ja kui jõulude eel koju saabusin, oli parajasti ilus suusailm. Võtsin juba teisel hommikul suusad ja koera ning läksin suusatama. Suusatasin hea tempoga, koer jooksis sabas, nuhkis vahepeal kõrkjates, siis jooksis tempokalt järele ja oli rõõmus. Järgmisel hommikul aga loom enam püsti ei saanud. Lamas ja niutsus. Helistasin oma arstist emale, see arvas, et kui koer igasugu asju tuustis, ju ta siis kusagilt koertekatku on korjanud, vaja arstile näidata. Kogu pere pakkis end koos koeraga taksosse-arvasime, et kui katk, siis see on ravimatu ja loom pannakse nüüd käsu korras magama. Koer oli aga loomakliinikus ennegi käinud ja teadis hästi, et seal tehakse süsti ja muidu haiget. Ning niipea, kui nad uksest sisse saime, olid loomal jalad all ja ta üritas uksest välja pääseda. Tõsi, jalad olid üksjagu kanged ja loomaarst leidis, et loom on lihtsalt liigset trenni teinud pärast pikka paigalolekut. Selgus, et mõned mehed olid koeraga küll maja otsa juures asjal käinud, kuid rohkem loom need kolm kuud-vastik sügistalvine aeg kah! - liikunud polnudki. Muidugi olid tal pärast rõõmsat jooksu lihased kanged ja valusad. Arstid muidugi üritasid mitme tuhande kroonist rohtu 


\section{Maarja Villandi}

ka kirjutada, aga selle jätsime siiski välja ostmata (naine, sünd 1960, jutustatud 2002 Tartus).

Mõni selline lugu on suisa traagilise lõpuga. Olen korduvalt kuulnud lugu perest, kus esimene tšau-tšau - need on need karupoja moodi karvased koerad - loomaomaniku lolluse tõttu suri. Nimelt olid jõukad loomapidajad sõitnud koos koeraga suvel Hiiumaale ja läksid ise ujuma. Koera aga jätsid autosse "vangi" - nad ei julgenud teda välja lasta ja puu külge siduda, sest kartsid, et vargad viivad kalli ja sõbraliku looma minema. Et ilm aga oli pööraselt palav ja autos olev umbne õhk kuumenes üle, sai loomake rabanduse ja suri. Pere võttis uue tšau-tšau, koguni samast pesakonnast. Olen lugu kuulnud mitmest allikast, kõik on esitanud lõpuks küsimuse: miks neile üldse sealt uus kutsikas anti?

Viimastel aastatel on levinud lood kurjadest ja ohtlikest koertest, kes on inimesi surnuks purenud. Niisuguseid lugusid on ka tõepoolest juhtunud. Nendest on kirjutatud ajakirjanduses (vt nt Postimehes ilmunud kirjutisi Ernits 2001a, 2001b, 2001c; Sildam 2001; Kagge 2000, 2001; Püüa 2001; Pau 2000a, 2000b; Kalda 2001) ja inimesed omakorda laiendavad neid, pakutakse uusi versioone.

Koerahammustuse ja puremise, aga ka lihtsalt ehmatamise lugusid räägitakse üldjuhul lapsepõlvemälestustena. Ka lapsed julgevad haiget saamisest avalikult rääkida. Täiskasvanueas hammustada saamisest räägitakse harva. Üks tüüpiline lugu:

Üks mu eakas meessugulane kardab väga koeri. Põhjuseks on lapsepõlves kogetud ehmatus. Nimelt olid kaks suurt koeravist dogid - ta poisikesena pikali ehmatanud. Ma tõesti ei mäleta, mis tõugu need koerad olid, kuid nii tema kui teised eakamad sugulased rõhutavad, et need polnud lihtsalt koerad, vaid tollase riigivanema koerad. Igatahes kardab see mees koeri tänini, kuigi kõik lähedased ta kallal sellepärast keelt teritavad (naine, sünd 1955, jutustatud 2002 Tartus).

Üldiselt eelistatakse küll rääkida lõbusaid lugusid, aga vahel räägitakse ka emotsionaalse värvinguga lugusid lemmikloomade alatisest ja ajutisest kadumisest ning surmast. Igaüks siiski neid lugusid suures seltskonnas ei räägi, kuid näiteks lapsepõlveloomade surmast või muidu kaugesse minevikku ulatuvaid lugusid 


\section{Maarja Villandi}

räägitakse meelsamini kui hiljutisi kurblugusid. Tavaliselt pole need küll esimesed lood, millest loomateemale minnes alustatakse, kuid nendeni võidakse jõuda. Üks mu tuttav rääkis lapsepõlveloo:

Tõime endale Värskast Tartusse uue kassi. Ta oli süsimust. Ühel päeval jäi ta haigeks. Ta oleks nagu aru saanud, et teda päästa ei õnnestu. Siis ta ronis kaminakorstnasse surema (jutustaja mees, sünd 1962, jutustatud Tartus 2004).

Eelistatavalt räägitakse lugusid, kus surma ennast ei pea nimetama - räägitakse lihtsalt looma kadumisest. Tavaliselt siis ei teatagi, mis temast sai. Vahel on neil lugudel ka õnnelik lõpp - lühema või pikema aja pärast ilmub loom uuesti välja.

Ei ole haruldased ka kontaminatsioonid, sest sageli ei räägi loomalood pelgalt ühest seigast, vaid loomadega seotud teemad põimuvad. Mida kauem on inimesel loom olnud, seda rohkem teemasid põimub. Mida pikemalt räägitakse loomadest, seda enam sügavuti minnakse. Põhjalikke loomalugusid räägitakse väikeses, kahe-kolme inimese seltskonnas, kus on tõenäolisem, et jutt kuulatakse ära. Selguse huvides on siiski eelistatumad lood, milles põimub kaks teemat ja need teemad on sageli lähedalt seotud. Siin-

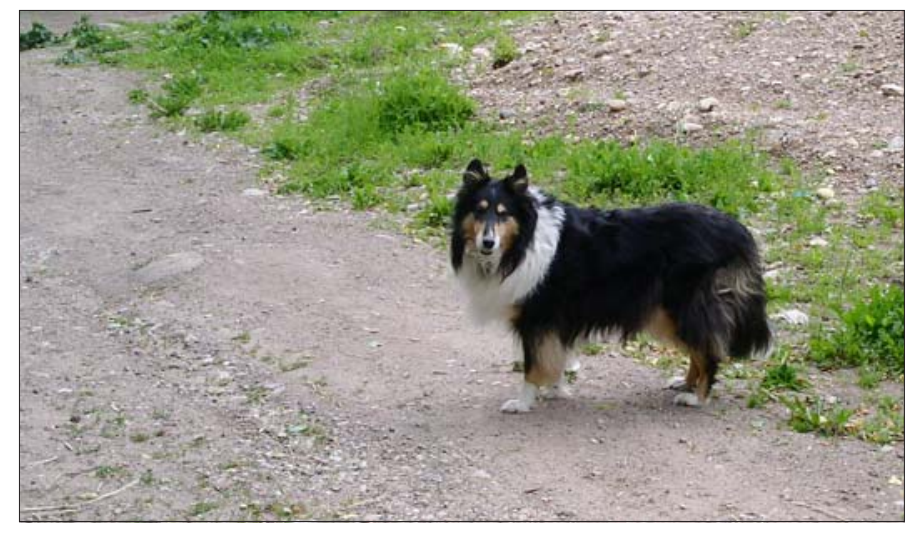

Foto 3. Mõtlik kolli Mustu. Vaikiv ja endassetõmbunud loom paneb inimesed kõnelema tema salapärasest sisemaailmast ja tabamatust tarkusest. Foto erakogust. 


\section{Maarja Villandi}

kohal näide loost, milles põimuvad lugu rumalatest koeraomanikest ja lugu kurjadest ja ohtlikest koertest. Lugu jutustati Belgias. See leidis laia kõlapinda ja sellel oli ka tõepõhi all, kuigi räägitav lugu on võtnud juba linnalegendi kuju ja vormi.

Kaks koerapidamises võhiklikku lapsevanemat võtsid endale kaks bullterjerit. Ilmselt seetõttu, et see koeratõug oli parasjagu moes. Siis aga tekkis lapsevanematel olukord, kus neil oli vaja lahutusest rääkida, ja seda loomulikult mitte kodus laste kuuldes. Niimoodi nad jätsid oma kaks last ja kaks bullterjerit koju luku taha ega andnud neile sü̈̈a. Kui nad koju tulid, leidsid nad oma lapsed bullterjerite poolt surnuks puretuna (mees, sünd 1949).

Alltoodud näites põimuvad loomade soetamise lood, lugu looma erilisest võimest tunnetada, lugu looma ajutisest kadumisest ja ka lugu loomade omavahelistest suhetest. Olen seda kuulnud oma perekonnas.

Pärast Laikat oli meil kaks koera-Prints ja Riki. Huvitav ongi see lugu, miks koeri oli kaks. Kui Laika vanaks ja vägaväga haigeks jäi, lasti ta magama panna. Aga paluti neil, kes ta ära viisid, vaadata, et kui kusagil noor koer palutakse magama panna, siis toodagu ta meile. Tõukoera ei tahetud, sest agulis pidasid kõik õuekoertena krantse - neid peeti tervemateks ja vastupidavamateks ning eelkõige oligi vaja valvurit. Meil asus üle tee näiteks Vene sõjaväeosa - seesama Marja tänava sõjaväeosas, õieti sõjaväe autobaas, millel polnud just hea kuulsus. (Praegu on seal Eesti kaitseväe tagalakompanii.)

Ühel päeval siis Prints toodigi. Et olla noor koer, kelle peremees suri, pärijad aga ei saa allergilise lapse pärast looma endale võtta. Pealegi olla see koer toda last korra ka hammustanud. Me võtsime koera, kuigi tundus, et ta väga noor enam polegi, tõenäoliselt oligi vähemalt viieaastane, ka hundi moodi nagu Laika, aga mitte nii tõupuhta väljanägemisega. Nimi oli tal uhke - Prints. Toojad teadsid öelda, et olla hea kuri valvur.

Aga koer ei tundunud üldse kuri, pigem liigagi leebe. Lapsed võisid teha temaga mida iganes. Kass võis tema sööki sü̈̈a ja kuuti ronida. Koer oli kuldkollane, säravama värviga kui 
saksa lambakoerad tavaliselt, aga laiema näoga. Ilmselt igatses ta taga oma surnud peremeest, sest ta ei võtnud ka eriti sü̈̈a vastu. Nii möödus päev, teine... Kolmandal hommikul koera polnud. Ta oli kaelarihma üle pea maha saanud ja võrgust koeraaia alla augu kaevanud ning kadunud. Ei tulnud ta tagasi ka õhtuks, järgmiseks õhtuks... Sai ka otsitud ja arutatud, et ju läks koer oma vanasse koju tagasi.

Aguli asi, inimesed kuulsid, et koer kadunud, ja min-

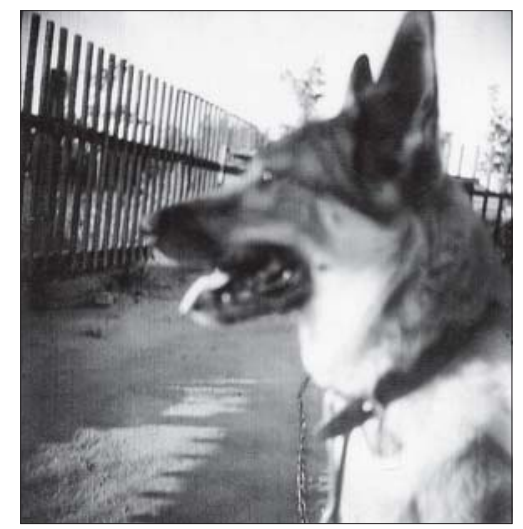

Foto 6. Printsi ja Riki eelkäija Laika on pererahva juturepertuaaris samuti olulisel kohal-näiteks osanud ta snepperlukku avada. Foto erakogust. gil hetkel tõi keegi teate, et kusagil Metalli või Mineraali tänavas liikuvat mingi tundmatu koer. Vanaisa läks vaatama. Seal oli tundmatu koer küll, aga mitte Prints. Oli üks väheldase hundi mõõtu lontkõrvadega krants, kes oli ilmselgelt maha jäetud. Näljas ja puha. Vanaisa tõi ta kaasa, et ikkagi koer ja olla teine juba nädalajagu päevi peremeheta olnud, vaid juhuslikult sü̈̈a saanud jne. Koer jäi meile, see oli päris noor kutsikas. Mänguhimuline ja lõbus. Kolis Printsi kuuti, sai tema keti ja valvas meie maja. Niipaljukest, kuipaljukest kutsikas valvab. Aga häält ikka tegi.

Kuid siis, kui kogu lootus oli kadunud, oli Prints ühel hommikul tagasi. Oli meie aias ja ootas sü̈̈a. Nü̈̈d osutus ta tõesti kurjaks ja iseloomuga koeraks, kuid noore kaaslase, kes oli vahepeal nimeks saanud Riki, tunnistas omaks. Kasse ta küll ei sallinud, ühe liialt julge koguni murdis, ja väga leplik ja leebe polnud ta ka. Kuid üldiselt sai temaga hakkama. Ainult ühe asjaga ta ei leppinud - tollaste tumedate krabisevast nailonist naiste vihmamantlitega. Selline oli mu vanaemal, kes Rootsimaalt vennalt pakke sai. Vanaema oli muidu Printsi sõber ja lemmik, sest tema andis sü̈̈a. Kuid kui ta oma nailonmantli selga pani, muutus koer raevukaks, nii et keegi pidi teda lausa kinni hoidma, et vanaema majast välja või 


\section{Maarja Villandi}

majja sisse saaks. Ju oli mõni sellist mantlit kandev inimene talle liiga teinud. Ju oli ta üldse tark loom, kes käis oma varasemat kodu korra vaatamas, ja, saanud aru, et seal pole enam kedagi, kes teda ootaks - teadsime, et see majagi mü̈̈di edasi -, tuli meile tagasi. Ja jäigi meie koeraks pikkadeks aastateks. Riki aga jäi vana koera kõrval ikka ja alati rumalaks, kuuletumatuks kutsikaks, kellest ainult Prints oma vanema looma autoriteediga jagu sai (naine, sünd 1955, jutustatud 2002 Tartus).

Miks ma aga ütlen, et PEAAEGU nagu inimene. Loomadest nimelt räägitakse küll kui lähedastest sotsiaalsetest olenditest, kuid siiski mitte päris nii nagu inimesest.

Esiteks. Looma võetakse juttudes ikkagi omandina (mul oli, tal oli...). Ka lapse või mehe kohta võidakse öelda, et mul on, kuid teda ei kujutata omandina.

Teiseks. Loomale andestatakse pahandused ja suliteod, neist räägitakse pigem heldimuse kui halvakspanuga. Kassi või koera vargapoisitempe peetakse looma arukuseks, mitte kasvatamatuseks. Ka paljud muud pahandused, mida isegi väikelapse tegudena häbenetakse, väärivad looma puhul imetlemist.

Kolmandaks. Loomade surmast ja kadumisest võidakse rääkida lõbusas seltskonnas. Inimese surmast räägitakse tavaliselt vaid väga intiimses ümbruses ja sellel on oma nukker alatoon, looma surmast rääkides ei pruugi see nii olla. Muidugi on inimesi, kes on kas alles hiljuti looma kaotanud või kellel on olnud oma loomaga eriliselt emotsionaalne suhe, ning nemad looma surmast kergel toonil ja suures seltskonnas ei räägi. Kuid samas kuuleb lugusid kunagi ammu peetud loomade surmast seltskondades üsna sageli.

Miks on põhjust rääkida loomadest jutustatud tõestisündinud või tõestisündinuks peetavatest lugudest kui folkloorist, kui pärimusest, samas kui varem selliseid lugusid rahvaluuleteaduses üldse ei käsitletud, määratletud ega uuritud? Täie kindlusega võib väita, et loomalood on pärimuslikud jutustused, kuna neid jutustatakse mälu põhjal ja neid ei ole eelnevalt ühestki kirjalikust allikast loetud. Määrav on isiklik kogemus või kelleltki teiselt kuuldud jutustus. Mis aga teeb loomajutud pärimuslikeks juttudeks ja seega ka folklooriks? Seda saab selgitada A. Kaivola-Bregenhøj väitega, et jutustuse esitaja teab juba oma eelnevast kogemusest, et 


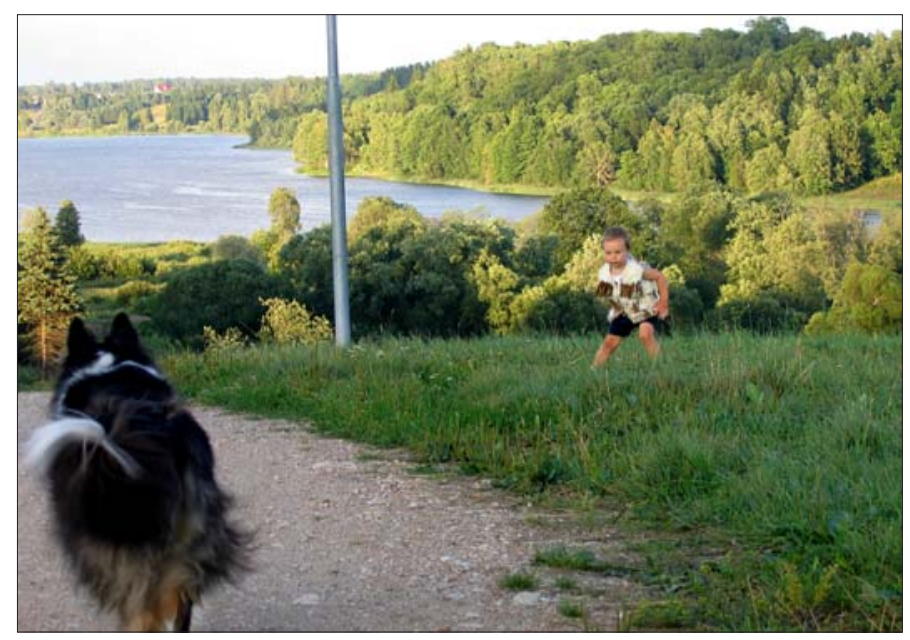

Foto 7. Kui lugu räägib loomadest ja lastest, räägib see pigem lastest. Niisamuti on piltidega perekonnaalbumis: kui pildil on laps, vaatab kaamerasse ja on keskel, loom all vasakus nurgas ja seljaga. Maarja Lõhmuse foto.

narratiivide struktuur on episoodiline ning iga episood koosneb üksteisega tahtlikus, põhjuslikus ja ajalises seoses olevatest osadest. Erinevatel esitustel võib erinevate osade rõhuasetus varieeruda (Kaivola-Bregenhøj 2000: 36).

Peale selle, et loomalugudel on olemas piisaval hulgal pärimuslike juttude tunnuseid, tuleb arvesse võtta ka rahvaluule käsitluse muutumist. Kuidas on rahvaluule käsitlemine muutunud? Folklorist Lauri Honko on välja toonud ühe tegurina, et on muutunud suhtumine informanti, pärimuse loojasse, vajajasse ja esitajasse, mis tähendab nende tähelepanuväärset võrdsustamist. Enam ei käsitleta rahvaluulekandjat kui reservuaari kuuluvat haruldust, vaid rahvaluulekandja võib olla igaüks ja rahvaluule varieerub vastavalt sotsiaalsele rühmale. Selle muudatuse kultuurifilosoofilise tulemusena on folkloor loomulik, koguni vältimatu suurus iga sotsiaalse rühma elus (Honko 1998).

Olen veendunud loomadest räägitud tõestisündinud lugude kui rahvaluule vormi uurimise vajalikkuses. Kuigi see on sageli lühivormiline ja seetõttu ühes loos üldjuhul palju motiive ei esine, on 


\section{Maarja Villandi}

siiski väga palju erandeid. Samuti tuleb tõdeda, et jutud lemmikloomadest on muutunud vältimatuks osaks inimestevahelises suhtlemises ja neil on täita oma ülesanne. Uurimise vajalikkuse põhjuseks võib tuua ka materjalikülluse.

Veel seostan loomadest räägitud tõestisündinud või tõestisündinuna võetavate lugude muutumist folklooriks sellega, et nendel aegadel, kui folkloori kandjaks peeti nn reservuaari elanikke, peeti loomi pigem funktsionaalsetel eesmärkidel (kass püüab hiiri, koer valvab jne), aga tänapäeval on neid järjest rohkem hakatud pidama meelelahutuslikel eesmärkidel, vahel ka lihtsalt üksinduse peletamiseks. Loomapidamine hobi korras loob nn klubilisi suhtlemisvorme ja kindlasti on ka põhjust rääkida näiteks koerteklubi või kassipidajate liidu folkloorist. Populaarsed on ka loomaarmastajate internetifoorumid ja internetifolkloori olemasolus ei kaheldagi.

\section{Allikad ja kirjandus}

Allikad

Maarja Villandi erakogu.

Mare Kõiva intervjuud Austraalia (2001) ja Rootsi (1996-1999) eestlastega.

\section{Kirjandus}

Dégh, Linda 1984. Erzähler. Ranke, Kurt et al. (toim). Enzyklopädie des Märchens: Handwörterbuch zur historischen und vergleichenden Erzählforschung 4: Ent-Fors. Berliin \& New York: de Gruyter, vrg 315-342.

Ernits, Peeter 2001a. Surm ootas 177 sammu kaugusel koduväravast. Postimees, 27. veebruar.

Ernits, Peeter 2001b. Võimalikud mõrtsukkoerad kadunud. Postimees, 14. märts.

Ernits, Peeter 2001c. Oli inimene, enam pole. Ja mis siis?: Aasta Marje surnukspuremisest. Postimees, 14. detsember.

Fischer, Helmut 2001. Jutustatud tegelikkus folkloriseerumisprotsessis. VTK raamat (http://www.folklore.ee/seminar/fischer.html - 2. november 2005). 


\section{Maarja Villandi}

Hiisjärv, Piret 2004. IV klassi eesti keele töökava (http://www.avita.ee/ pdf/tunnijaotuskava\%2Feesti\%204kl.indd.doc - 2. november 2005).

Holbek, Bengt 1990. The Family Anecdote: Event and Narrative. Röhrich, Lutz \& Wienker-Piepho, Sabine (toim). Storytelling in Contemporary Societies. ScriptOralia 22. Tübingen: Narr, lk 103-112.

Honko, Lauri 1998. Folklooriprotsess. Mäetagused: Hüperajakiri 6, lk 5684 (vt ka http://www.folklore.ee/tagused/ - 10. september 2005).

Jackson, Bruce 1987. Fieldwork. Urbana: University of Illinois Press.

Kagge, Rasmus 2000. Harjumaal ründas hulkuv koer taas inimest. Postimees, 19. detsember.

Kagge, Rasmus 2001. Postimees elustas mõrtsukkoerte otsimise. Postimees, 1. märts.

Kaivola-Bregenhøj, Annikki 2000. Miks me mäletame nii, nagu me mäletame? Mäetagused: Hüperajakiri 15, lk 35-47 (vt ka http://www.folklore.ee/ tagused - 12. september 2005).

Kalda, Erik 2001. Valvekoerad tapsid Kohtla-Järvel oma toitja. Postimees, 20. november.

Labov, William 2001. Paljastades narratiivi sündmusstruktuuri. VTK raamat (http://www.folklore.ee/seminar/labov1.html - 12. detsember 2005).

Lappints, Virág \& Bárt, Dániel 2005. Narratives about Dogs in an Anthropological Context. Folk Narrative Theories and Contemoprary Practices: $14^{\text {th }}$ Congress of the International Society for Folk Narrative Research (ISFNR): Juli 26-31 2005, Tartu, Estonia: Abstracts. Tartu: Estonian Literary Museum \& University of Tartu, lk 170.

Nagy, Ilona 2000. Traditsiooniliste narratiivide stsenaarium igapäevases suhtlemises. VTK raamat (http://www.folklore.ee/seminar/nagy.html 12. detsember 2005).

Pau, Martin 2000a. Koerad puresid Tartus surnuks väikese poisi: Lapsel oli läbi näritud kõri ning sääreluult oli söödud liha. Postimees, 17. jaanuar.

Pau, Martin 2000b. Eksperdid kinnitavad tapjakoerte süüd: Tartus kaheksa-aastase poisi tapnud koerte omanik pidas 20 -pealist metsikut koerakarja. Postimees, 18. jaanuar.

Püüa, Marko 2001. Loomad ründavad inimesi sama tihti nagu pool sajandit tagasi. Postimees, 30. oktoober.

Sildam, Toomas 2001. Mõrtsukkoertega seonduv uurimisplaan täidetud. Postimees, 14. märts. 


\section{Maarja Villandi}

Storytelling 1997. English Language Arts: A Curriculum Guide for the Middle Level (Grades 6-9). Regina (Saskatchewan): Saskatchewan Education (http://www.sasked.gov.sk.ca/docs/mla/speak014.html - 2. november 2005). 